\title{
Association between body iron stores and level of oxidatively modified DNA bases
}

\author{
TOMASZ DZIAMAN*, MAREK JURGOWIAK, RYSZARD OLIŃSKI \\ Department of Clinical Biochemistry, Ludwik Rydygier Collegium Medicum in Bydgoszcz, Nicolaus Copernicus University in Toruń \\ * Corresponding author: tomekd@cm.umk.pl
}

\begin{abstract}
It appears that the presence of labile iron pool (LIP, iron not bound to proteins) in cells can result in the production of reactive oxygen species namely ${ }^{\circ} \mathrm{OH}$ radical which may be responsible for the formation of 8-oxo-7,8-dihydro-2'-deoxyguanosine (8-oxodG) in the cellular DNA. This oxidatively modified molecule is regarded as a good biomarker of cancer risk and a general index of oxidative stress in relation to other diseases. There are numerous data suggesting that oxidative stress may be involved in the development of cardiovascular diseases and cancer. It has been observed that heterozygosity for hereditary hemochromatosis (a disease with abnormal iron storage) is a risk factor for vascular diseases. Previously we have demonstrated higher levels of LIP in a group of atherosclerotic patients when compared with the control group. This suggests that LIP may increase the risk of disease development. The aforementioned condition may lead to oxidative stress, which is manifested by a higher level of 8-oxodG in blood lymphocytes, and may be one of the factors responsible for the development of cardiovascular diseases. We have also reported the relationship between LIP and the endogenous level of 8-oxodG in human lymphocytes of the colon cancer patients. Good correlation has been determined between LIP and oxidatively modified nucleoside. The results of our studies on piglets supplemented with iron dextran (FeDex) also show an increase in the 8-oxodG level in hepatic DNA. These findings confirm the possibility that iron overload may favor the persistence of harmful LIP which may catalyze generation of the potentially carcinogenic 8-oxodG moiety in the cellular DNA.
\end{abstract}

Key words: labile iron pool, oxidative stress, 8-oxodG

\section{Introduction to iron metabolism and generation of Reactive Oxygen Species}

Iron plays a pivotal role in many crucial biological processes, because it can serve either as an electron donor or electron acceptor, alternating between ferrous $\left(\mathrm{Fe}^{2+}\right)$ and ferric $\left(\mathrm{Fe}^{3+}\right)$ ion, but this ability makes this metal both profitable and dangerous. Due to its features of a transition metal, it is a useful component of many enzymes and proteins (McCord, 1998) involved in mitochondrial respiration, electron transfer, oxygen transport, DNA synthesis and repair. The distribution and amount of iron in tissues of the human body are shown in Figure 1.

Due to its features, iron is a precious element for the organism, and for that reason iron metabolism is tightly controlled in mammalian cells by proteins such as transferrin, ferritin or hemosiderin that bind iron. Iron ions that circulate in the blood plasma are bound to plasma transferrin, whereas the excess of iron in cells is accumulated in complex with ferritin (Epsztejn et al.,
1997; Bolann and Ulvik, 1990; Olinski and Jurgowiak, 1996). If necessary, iron can be released as a result of either ferritin degradation in lysosomes or directly from native protein. Also, a mitochondrial form of ferritin exists in cells. An increased concentration of this protein is observed in the erythroid cells from patients with sideroblastic anemia, where mitochondria are overloaded with iron (Cazzola et al., 2003). Hepcidin, a peptide, has an influence on iron absorption in enterocytes, while its recirculation from macrophages plays a special role in iron metabolism. Excessive synthesis of this peptide may induce accumulation of iron ions in these cells (Rossi, 2005).

Iron bound to proteins is safe for organisms and in this form it is involved in different physiological functions. Inside the cell, iron can also exist in another form, as a "free" or "labile" iron (LIP, iron not bound to proteins). LIP-associated iron is in a dynamic equilibrium with sequestered iron forms in cell and is bound to cytosolic low-molecular weight ligands that have not yet been 


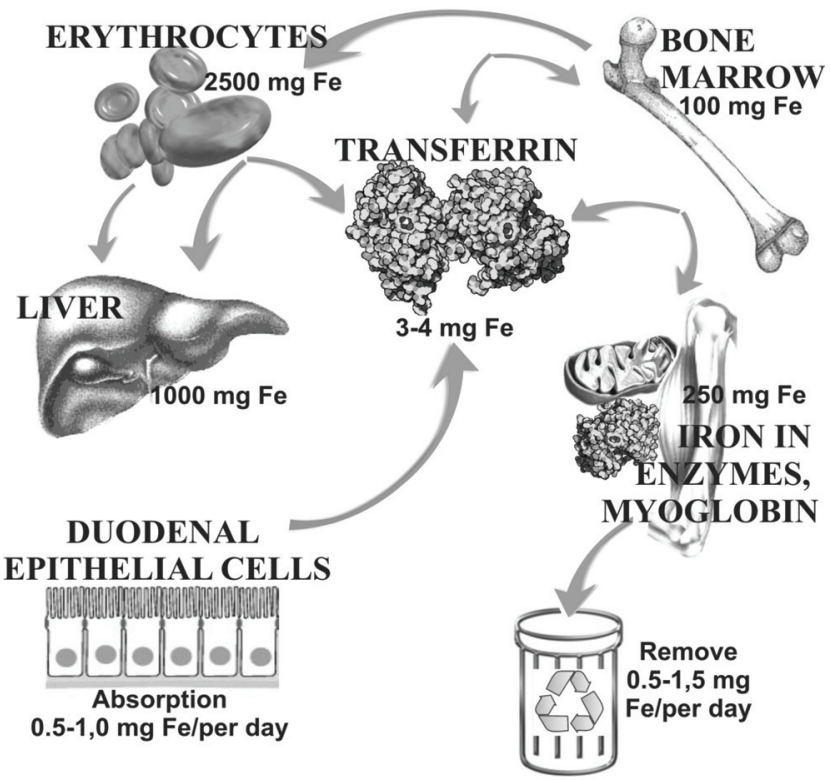

Fig. 1. Iron storage in human body (adapted and modified from Oliński and Jurgowiak, 2002)

identified. When the amount of iron in the serum exceeds the binding capacities of transferrin, then ions of this metal remain in a pool described as "non transferrinbound iron" (NTBI), which may influence the level of cellular labile iron pool. This iron form is catalytically active and participates in the production of toxic reactive oxygen species (ROS) via Fenton reaction. Interaction of ROS with cellular components may result in damage to biomolecules, including DNA, lipids and proteins (Emerit, Beaumont, Trivin, 2001) - see Figure 2, which in turn may lead to an increased risk of cancer, coronary heart or neurodegenerative diseases (Olinski and Jurgowiak, 2003; Olinski et al., 2002; Andrews, 2000). The risk of these pathologies development is higher when iron concentration exceeds the binding capacities of the aforementioned proteins.

ROS are the products of partial reduction of oxygen. These species, which include superoxide anion $\left(\mathrm{O}_{2}^{--}\right)$, hydrogen peroxide $\left(\mathrm{H}_{2} \mathrm{O}_{2}\right)$ and hydroxyl radical $\left({ }^{\circ} \mathrm{OH}\right)$, are continuously produced in living cells as by-products of normal metabolism (McCord, 1998; Olinski and Jurgowiak, 1996; Bartosz, 1995). During mitochondrial respiration, up to $1-5 \%$ of oxygen undergoes single electron transfer that generates the superoxide anion radical in amounts corresponding to about $2 \mathrm{~kg}$ per year for a human being (Olinski and Jurgowiak, 2003). ROS have been postulated to play a significant role in the etiology

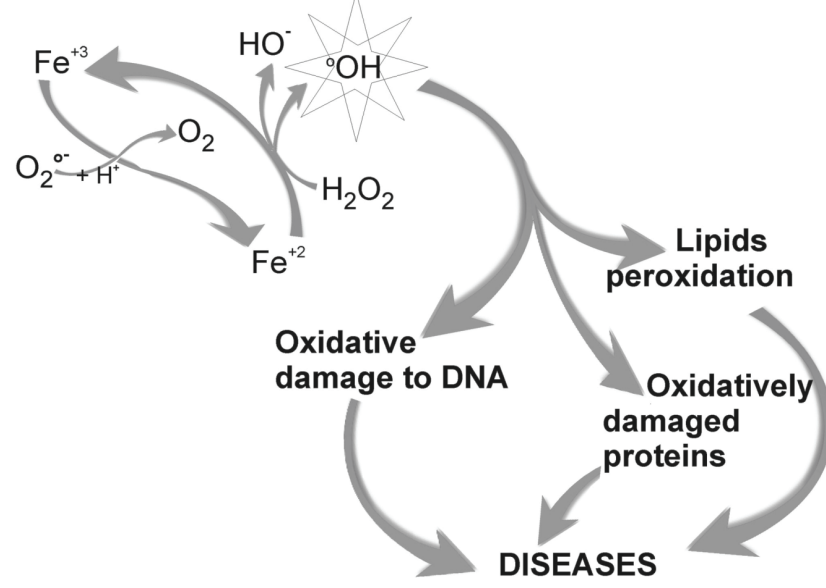

Fig. 2. Fenton reaction and its repercussions. Generated ${ }^{\circ} \mathrm{OH}$ radical can damage lipids, proteins and nucleic acids. It may lead to dysfunctions of the cells and development of diseases

of at least 50 diseases including rheumatoid arthritis, cancer, atherosclerosis, myocardial infraction, Parkinson's disease and AIDS (Olinski and Jurgowiak, 2003; Olinski et al., 2002). Reperfusion of ischemic tissues and chronic inflammation also lead to ROS generation. Furthermore, UV and ionizing irradiation, a wide variety of drugs and xenobiotics can also stimulate the formation of ROS. A variety of carcinogens, including benzene, aflatoxin and benzopyrene may exert their effect partly through the generation of ROS during their metabolism. The superoxide radical is degraded by superoxide dismutase (SOD) and hydrogen peroxide by catalase. However, the reaction of hydrogen peroxide with transition metal ions, like iron, leads to highly reactive hydroxyl radical $\left({ }^{\circ} \mathrm{OH}\right)$ and interaction of this radical with cellular components may result in damage to biomolecules including DNA (Olinski and Jurgowiak, 1999).

There are experimental data which demonstrate the existence of a free iron pool in the sera of patients with hemochromatosis - the disease with abnormally high iron storage resulting from excessive iron absorption. Several types of this disease are known: type 1 caused by inactivation of the $H F E$ gene and four types (2A, 2B, $3,4)$ characterized as non- $H F E$ hereditary hemochromatosis (Roetto and Camaschella, 2005). This disease predisposes to cancer and cardiovascular diseases (CVD). Epidemiological data also suggest that elevation of the body iron levels may increase the risk of cancer and atherosclerosis (Andrews, 2000; Rossi et al., 2000). Our results suggest a mechanism that may directly link iron 
overload with carcinogenesis and atherosclerosis. Specifically, iron overload may favor the persistence of harmful LIP, which may be responsible for LDL oxidation as well as may catalyze generation of the potentially carcinogenic oxidatively modified DNA bases in the cellular DNA (Gackowski et al., 2001).

\section{Oxidative damage to DNA}

In living cells, there is a steady formation of DNA lesions arising from normal cellular metabolism as well as pathophysiological processes and extracellular sources. A substantial number of these lesions are formed by endogenous factors that damage DNA on a continuous basis. A free radical attack upon DNA generates a whole series of DNA damage, including modified DNA bases. Certainly, not all ROS can damage DNA directly (Halliwell and Cross, 1994). For example, $\mathrm{H}_{2} \mathrm{O}_{2}$ and $\mathrm{O}_{2}^{--}$may initiate DNA damage by interacting with transition metal ion, in particular, iron and copper, in Haber-Weiss type reaction, producing ${ }^{\circ} \mathrm{OH}$. The hydroxyl radical is one of the most reactive species responsible for the formation of a large number of pyrimidine and purine-derived lesions in DNA (reviewed in: Dizdaroglu, 1993). Examples of such lesions are presented in Figure 3. Some of these modified DNA bases have a considerable potential to damage the integrity of nuclear and mitochondrial genomes (reviewed in: Floyd, 1990; Jackson and Loeb, 2001). The levels of oxidative damage to mtDNA are several times higher than those of nuclear DNA (Sastre et al., 2000).
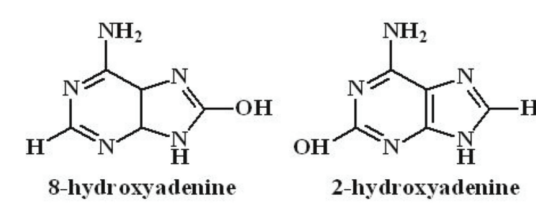

2-hydroxyadenine

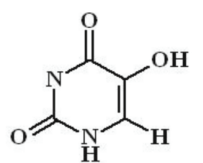

5-hydr oxyuracil
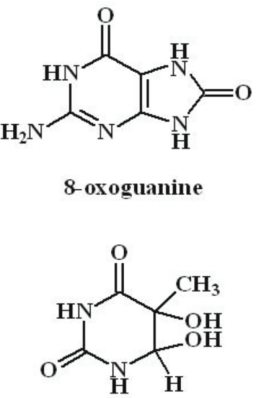

thymine glycol

Fig. 3. Examples of oxidatively modified DNA bases

One of the most widely studied lesions is 7.8-dihydro8-oxoguanine (8-oxoGua) and its nucleoside (8-oxodG). The presence of 8-oxo-7,8-dihydro-2'-deoxyguanosine resi-

dues in DNA leads to $\mathrm{GC} \rightarrow \mathrm{TA}$ transversions unless repaired prior to DNA replication (Cheng et al., 1992). Therefore, the presence of 8-oxodG in cells may lead to point mutations. This oxidative DNA adduct is regarded as a good biomarker of cancer risk from oxidative stress, for the investigations of effectiveness of dietary antioxidants and as a general index of oxidative stress in relation to other diseases such as CVD.

Several other modified bases such as 2-hydroxyadenine (2-OH-Ade), 8-hydroxyadenine (8-OHAde), 5-hydroxycytosine (5-OH-Cyt), and 5-hydroxyuracil (5-OH-Ura) have also been shown to possess miscoding potentials and may be premutagenic as well (reviewed in: Wallace, 1998), but their biological properties are not yet fully recognized.

\section{Labile iron pool and atherosclerosis}

The possibility that iron overload may play an important role in CVD was put forward in 1981 by J. L. Sullivan (Sullivan, 1981). Now there are increasing epidemiological evidences concerning the role of iron in atherosclerosis (Kiechl et al., 1997; de Valk and Marx, 1999). Interestingly, it was found that heterozygosity for type 1 hereditary hemochromatosis is a risk factor for vascular diseases (Kiechl et al., 1994). There are also some evidences that iron depletion protects from atherosclerosis and CVD (Roest et al., 1999). In this context, it is interesting to note that in premenopausal women the incidence of atherosclerosis and CVD is less than half that of age-matched men (McCord, 1998; Emerit, Beaumont and Trivin, 2001). One of the possible explanations for this finding may be that depletion of iron stores by regular menstrual blood loss may be a source of protection of premenopausal subjects.

Our data also suggest that iron metabolism may have some influence on atherosclerosis development. In agreement with previous studies, we have found that ferritin concentration was higher in atherosclerotic patients than in the control group (although these changes were statistically insignificant) (Gackowski et al., 2001). In this context, it should be noted that increased ferritin concentration generally reflects iron stores but may also be related to high alcohol consumption, cancer and inflammation (Looker and Johnson, 1998). In our study, we also decided to analyze labile iron pool (LIP) in human lymphocytes - which is involved in the production of harm- 
ful ROS. Interestingly, LIP in lymphocytes of the atherosclerotic patient group was about two times higher than that in the control group.

Moreover, we found that the level of 8-oxodG in lymphocytes of atherosclerotic patients was significantly higher than in DNA of the control group (12.78 and 9.80 lesions $/ 10^{6} \mathrm{dG}$ respectively. In another study which involved healthy people (Nakano et al., 2003), a positive correlation between urinary 8-oxodG and serum ferritin was shown, which suggested that iron status may influence the generation of 8-oxodG, in vivo. Experimental evidence suggests that urinary excretion of 8-oxodG represents repair processes, namely removal of oxidatively modified base/nucleoside at the level of whole body (Olinski et al., 2003).

These changes may have some influence on the development of atherosclerosis in the following way. The plaques of the arterial walls, among other components, contain lymphocytes (Gackowski et al., 2001). Since 8-oxodG has mutagenic properties and is a block to transcription in mammalian cells (Le Page, 2000), it is possible that lymphocytes with higher amount of this modified base trapped into the plaque, can more easily be involved in initiation-promoting process. There are suggestions that this process may be responsible for the formation of the atherosclerotic lesion. Thereafter, the higher amount of trapped cells can lead to more advanced lesions. Moreover, there are some experimental data which strongly suggest that the elevated level of 8-oxodG found in the lesion of the aorta walls of atherosclerotic patients, may be one of the events directly involved in the development of the disease (Collins et al., 1998).

Our data confirms the hypothesis that higher levels of LIP may increase the risk of the atherosclerosis development. Progress of this pathology is associated with inflammatory condition and oxidative stress, which is, in turn, manifested by a higher level of 8-oxodG in blood lymphocytes. It is possible that this condition may be a factor responsible for the development of atherosclerosis (Gackowski et al., 2001).

\section{Body iron stores and cancer}

Iron-induced free radical damage to DNA seems to be important for the development of cancer. Tumor cells are known as the rapidly growing cells in response to iron (Ullen et al., 1997). Carcinogenicity of iron overload was demonstrated clearly in many animal experiments (Campbell, 1940; Richmond, 1959; Li et al., 1987; Liu and Okada, 1994).

Body iron stores and dietary iron intake have been shown to be positively correlated with the risk of human colon cancer (Nelson et al., 1994; Stevens et al., 1998). In our study, carcinoma patients showed statistically significant lower values of transferrin saturation, total iron binding capacity and serum iron level when compared with the control group (Gackowski et al., 2002A). Functional iron deficiency can occur during the cancer and chronic inflammation states and is often associated with relatively high iron levels in the liver as an effect of enhanced hepcidine biosynthesis (Weiss, 2009).

In our above-mentioned work (Gackowski et al., 2002a), it was reported that mean values of LIP in lymphocytes of the patient group were higher than in the control ones, but these differences were not statistically significant. Rather insignificant differences in LIP and ferritin concentrations observed in this study may be explained, at least in part, by a large individual variability of those parameters. Such huge individual differences in ferritin concentration have also been reported by others (Nelson et al., 1994). Since this was the first in vivo study of LIP in human lymphocytes, it was difficult to compare the obtained results with other data reported in literature. However, the concentration found in our study is comparable to the levels estimated for different types of mammalian cultured cells (Lipinski et al., 2000). It is possible that higher concentrations of LIP in the lymphocytes of patients with carcinoma may be explained by the distinctive behaviour of ferritin observed in our report, i.e. high level of intracellular LIP may cause an increase in ferritin synthesis and determine high plasma concentrations of ferritin. Since LIP can influence the production of ROS, our results support a recent observation that oxidative stress may be responsible for impaired lymphocyte function in cancer patients (Schmielau and Finn, 2001).

Usually, in malignant diseases plasma iron level falls due to cytokines activity (Halliwell and Gutterige, 1999). Our observations support an interesting hypothesis which suggests that the observed changes lead to the restriction of iron availability for tumour cells thus slowing tumor growth (Weinberg, 1996). 


\section{Iron supplementation and level of oxidatively damaged DNA}

Iron supplementation is a frequently practised treatment in the occurrence of iron deficiency anaemia (IDA), which is most prevalent during the neonatal period and in early childhood. IDA is probably the most prevalent micronutrient deficiency disorder in newborn piglets, due to their rapid growth (Svoboda and Drabek, 2005). Intramuscular administration of large amounts of iron compounds can cure those deficiencies. However, iron overload is dangerous, because unbound ions are catalytically active. As it was mentioned above, in our previous study, we observed a strong correlation between iron content and the levels of oxidatively modified nucleoside in lymphocytes' DNA (Gackowski et al., 2002b). Therefore, besides the efficacy in curing iron deficiency, one of the main criteria for selecting an iron supplementation protocol is that the supplemental iron should produce minimal toxicity.

In our recent studies (Lipinski et al., 2010), anaemic neonatal pigs were supplemented with iron dextran (FeDex). They were allotted to one of three different experimental groups on the basis of body weight (b.w.) at the given experimental age, control piglets receiving no iron supplementation; piglets intramuscularly injected in the neck with $100 \mathrm{mg} \mathrm{Fe} / \mathrm{kg}$ b.w. on day 3 postpartum (traditional supplementation); piglets injected with $40 \mathrm{mg} \mathrm{Fe} / \mathrm{kg}$ b.w. on day 3 and again on day 10 postpartum (modified supplementation). The results demonstrated that points with the highest iron concentrations were related to the highest 8-oxodG levels. Furthermore, the modified iron supplementation was linked with a significantly smaller increase in 8-oxodG level in hepatic DNA when compared with the traditional protocol.

Although the oxidative stress observed in newborn piglets may be, partly, as a result of a sudden increase in oxygenation after birth (Dziaman et al., 2007), the intramuscular injection resulted in elevated amounts of iron in the colon and subsequent increase in oxidative stress, as measured by increased levels of 8-oxodG in colon DNA and increased urinary excretion of 8-oxoGua (Langie et al., 2010). Similar observations upon injection with FeDex were previously reported in rats (Wellejus, Poulsen, Loft, 2000).

In the study with young children_(1-4 years old) with IDA that were orally supplemented with $\mathrm{Fe}^{3+}$ preparation for 12 weeks, an increase in the oxidative damage to
DNA was observed. However, this growth was free from the corresponding changes in the serum level of iron and ferritin. These changes could have been a result of an increased oxidative stress due to an accelerated metabolic rate by the rehabilitation of oxygenation in the organism (Aksu et al., 2010).

It appears that misregulation of iron administration influences organism's homestasis. The presence of an excessive amount of iron in cells or/and extracellular spaces can result in the production of ROS and induction of oxidatively damaged DNA. Specifically, iron overload may favor the persistence of harmful LIP, which may catalyze the generation of potentially carcinogenic 8-oxodG moiety in the cellular DNA.

\section{References}

Aksu B.Y., Hasbal C., Himmetoglu S., Dincer Y., Koc E.E., Hatipoglu S., Akcay T. (2010) Leukocyte DNA damage in children with iron deficiency anemia: effect of iron supplementation. Eur. J. Pediatr. 169(8): 951-956.

Andrews N.C. (2000) Iron homeostasis: insights from genetics and animal models. Nature Rev. Genet. 1: 208-217.

Bartosz G. (1995) Druga twarz tlenu. Wydawnictwo Naukowe PWN, Warszawa.

Bolann E.J., Ulvik R.J. (1990) On the limited ability of superoxide to release iron from ferritin. Eur. J. Biochem. 193: 899-904.

Campbell J.A. (1940) Effects of precipitated silica and of iron oxide on the incidence of primary lung tumours in mice. Br. Med. J. 275-280.

Cazzola M., Invernizzi R., Bergamaschi G., Levi S., Corsi B., Travaglino E., Rolandi V., Biasiotto G., Drysdale J., Arosio P. (2003) Mitochondrial ferritin expression in erythroid cells from patients with sideroblastic anemia. Blood 101(5): 1996-2000.

Cheng K.C., Cahill D.S., Kasai H., Nishimura S., Loeb L.A. (1992) 8-Hydroxyguanine, an abundant form of oxidative $D N A$ damage, causes $G \rightarrow T$ and $A \rightarrow C$ substitution. J. Biol. Chem. 267: 166-172.

Collins A.R., Gedik C.M., Olmedilla B., Southon S., Belizzi M. (1998) Oxidative DNA damage measured in human lymphocytes: large differences between sexes and between countries and correlation with heart disease mortality rates. FASEB J. 12: 1397-1400.

Dizdaroglu M. (1992) Oxidative damage to DNA in mammalian chromatin. Mutat. Res. 275: 331-342.

Dziaman T., Gackowski D., Rozalski R., Siomek A., Szulczynski J., Zabielski R., Olinski R. (2007) Urinary excretion rates of 8-oxoGua and 8-oxodG and antioxidantvitamins level as ameasure of oxidative status in healthy, full-term newborns., Free Radic. Res. 41: 997-1004.

Emerit J., Beaumont C., Trivin F. (2001) Iron metabolism, free radicals, and oxidative injury. Biomed. Pharmacother. 55: 333-339. 
Epsztejn S., Kakhlon O., Glickstein H., Breuer W., Cabantchick Z.I. (1997) Fluorescence analysis of the labile iron pool in mammalian cells. Anal. Biochem. 248: 31-40.

Floyd R.A. (1990) The role of 8-hydroxyguanine in carcinogenesis, Carcinogenesis 11: 1447-1450.

Gackowski D., Kruszewski M., Jawień A., Ciecierski M., Oliński R. (2001) Further evidence that oxidative stress may be a risk factor responsible for the development of atherosclerosis. Free Rad. Biol. Med. 31: 542-547.

Gackowski D., Kruszewski M., Banaszkiewicz Z., Jawien A., Olinski R. (2002a) Lymphocyte labile iron pool, plasma iron, transferrin saturation and ferritin levels in colon cancer patients. Acta Bioch. Pol. 49: 269-272.

Gackowski D., Kruszewski M., Bartlomiejczyk T., Jawien A., Ciecierski M., Olinski R. (2002b) The level of 8-oxo-7,8dihydro-2'-deoxyguanosine is positively correlated with the size of the labile iron pool in human lymphocytes. J. Biol. Inorg. Chem. 7: 548-550.

Halliwell B., Cross C.E. (1994) Oxygen-derived species: their relation to human disease and environmental stress. Environ. Health Perspect. 102(Suppl 10): 5-12.

Halliwell B.M., Gutterige J.M.C. (1999) Free Radicals in Biology and Medicine. Oxford University Press Inc., New York.

Jackson A.L., Loeb L.A. (2001) The contribution of endogenous sources of DNA damage to the multiple mutations in cancer. Mutat. Res. 477: 7-21.

Kiechl S., Aichner F., Gerstenbrand F., Egger G., Mair A., Runnger G., Spogler F., Jarosch E., Oberhollenzer F., Willeit J. (1994) Body iron stores and presence of carotid atherosclerosis: results from the Bruneck study. Arterioscler. Thromb. 14: 1625-1630.

Kiechl S., Willeit J., Egger G., Egge G., Poewe W. (1997) Body iron stores and the risk of carotid atherosclerosis. Prospective results from the Bruneck study. Circulation 96: 3300-3307.

Langie S.A., Kowalczyk P., Tudek B., Zabielski R., Dziaman T., Oliński R., van Schooten F.J., Godschalk R.W. (2010) The effect of oxidative stress on nucleotide-excision repair in colon tissue of newborn piglets. Mutat. Res. 695(1-2): 75-80.

Li J.L., Okada S., Hamazaki S., Ebina Y., Midorikawa O. (1987) Subacute nephrotoxicity and induction of renal cell carcinoma in mice treated with ferric nitrilotriacetate. Cancer Res. 47: 1867-1869.

Lipinski P., Drapier J.-C., Oliveira L., Retmanska H., Sochanowicz B., Kruszewski M. (2000) Intracellular iron status as a hallmark of mammalian cell susceptibility to oxidative stress: A study of L5178Y mouse lymphoma cell lines differentially sensitive to H2O2. Blood, 95: 2960-2966.

Lipinski P., Starzyński R.R., Canonne-Hergaux F., Tudek B., Oliński R., Kowalczyk P., Dziaman T., Thibaudeau O., Gralak M.A., Smuda E. et al. (2010) Benefits and risks of iron supplementation in anemic neonatal pigs. Am. J. Pathol. 177(3): 1233-1243.

Liu M., Okada S. (1994) Induction of free radicals and tumors in the kidneys of Wistar rats by ferric ethylenediamine$N, N$ '-diacetate. Carcinogenesis, 15: 2817-2821.
Looker A.C., Johnson C.L. (1998) Prevalence of elevated serum transferrin saturation in adults in United States. Ann. Intern. Med. 129: 940-945.

McCord J.M. (1998) Sem. Iron, free radicals, and oxidative injury. Hematology 35: 5-12.

Nakano M., Kawanishi Y., Kamohara S., Uchida Y., Shiota M., Inatomi Y., Komori T., Miyazawa K., Gondo K., Yamasawa I. (2003) Oxidative DNA damage (8-hydroxydeoxyguanosine) and body iron status: a study on 2507 healthy people. Free Radic. Biol. Med. 35(7): 826-832.

Nelson R.L., Davis F.G., Sutter E., Sobin L.H., Kikendall J.W., Bowen P. (1994) Body iron stores and risk of colonic neoplasia. J. Natl. Cancer Inst. 86: 455-460.

Oliński R., Jurgowiak M. (1996) Reaktywne formy tlenu - uniwersalny czynnik patogenny? [in:] Nowe tendencje w biologii molekularnej $i$ inżynierii genetycznej oraz medycynie, ed. Barciszewski J., Łastowski K., Twardowski T., Wydawnictwo Sorus, Poznań: 373-400.

Oliński R., Jurgowiak M. (1999) Oksydacyjne uszkodzenia DNA (8-oksodG) - biomarkerem niektórych chorób człowieka. Kosmos, 48: 329-338.

Olinski R., Gackowski D., Foksinski M., Rozalski R., Roszkowski K., Jaruga P. (2002) Oxidative DNA damage: assessment of the role in carcinogenesis, atherosclerosis, and acquired immunodeficiency syndrome. Free Radic. Biol. Med. 33(2): 192-200.

Oliński R., Jurgowiak M. (2002) Iron metabolism, oxidative DNA damage and atherosclerosis. Acta Angiol. 8(2): 37-44.

Olinski R., Jurgowiak M. (2003) Uszkodzenia DNA przez wolne rodniki tlenowe - konsekwencje biologiczne i implikacje kliniczne. [in:] Na pograniczu chemii i biologii, vol. VII, Wydawnictwo Naukowe UAM, Poznań.

Olinski R., Gackowski D., Rozalski R., Foksinski M., Bialkowski K. (2003) Oxidative DNA damage in cancer patients: a cause or a consequence of the disease development? Mutat. Res. 531: 177-190.

Le Page F., Kwoh E.E., Avrutskaya A., Gentil A., Leadon S.A., Sarasin A., Cooper P.K. (2000) Transcription-coupled repair of 8-oxoguanine, requirement for XPG,TFIIH, and CSB, and implications for Cockayne Syndrom. Cell, 101: 158-171.

Richmond H.G. (1959) Induction of sarcoma in the rat by irondextran complex. Br. Med. J. 947-949.

Roest M., van der Schouw Y.T., de Valk B., Marx J.J., Tempelman M.J., de Groot P.G., Sixma J.J., Banga D. (1999) Heterozygosity for a hereditary hemochromatosis gene is associated with cardiovascular mortality in women. Circulation 100: 1268-1273.

Roetto A., Camaschella C. (2005) New insights into iron homeostasis through the study of non-HFE hereditary haemochromatosis. Best Pract. Res. Clin. Haematol. 18(2): 235-250.

Rossi E., Brendan M., McQuillan M., Hung J., Thompson P.L., Kuek C., Beilby J.P. (2000) Serum ferritin and C282Y mutation of the hemochromatosis gene as predictors of asymptomatic carotid atherosclerosis in a community population. Stroke 31: 3015-3020. 
Rossi E. (2005) Hepcidin - the Iron Regulatory Hormone. Clin. Biochem. Rev. Vol. 26: 47-49.

Sastre J., Pallardó F.V., García de la Asunción J., Viña J. (2000) Mitochondria, oxidative stress and aging. Free Radic. Res. 32(3): 189-198.

Schmielau J., Finn O.J. (2001) Activated granulocytes and granulocyte-derived hydrogen peroxide are the underlying mechanisms of suppression of T-cell function in advanced cancer patients. Cancer Res. 61: 4756-4760.

Stevens R.G., Jones D.Y., Micozzi M.S., Taylor P.R. (1998) Body iron stores and the risk of cancer. N. Engl. J. Med., 319: 1047-1052.

Sullivan J.L. (1981) Iron and the sex difference in heart disease risk. Lancet 1: 1293-1294.

Svoboda M., Drabek J. (2005) Iron deficiency in suckling piglets: etiology, clinical aspects and diagnosis. Folia Vet. 49: 104-111.
Ullen H., Augustsson K., Gustavsson C., Steineck G. (1997) Supplementary iron intake and risk of cancer: reversed causality? Cancer Lett. 114: 215-216.

de Valk B., Marx J.J.M. (1999) Iron, atherosclerosis and ischemic heart disease. Arch. Intern. Med. 159: 1542-1548.

Wallace S.S. (1998) Enzymatic processing of radiation-induced free radical damage in DNA. Radiat. Res. 150: 60-S79.

Weinberg E.D. (1996) The role of iron in cancer. Eur. J. Cancer Prevent. 5: 19-36.

Weiss G. (2009) Iron metabolism in the anemia of chronic disease. Biochim. Biophys. Acta 1790: 682-693.

Wellejus A., Poulsen H.E., Loft S. (2000) Iron-induced oxidative DNA damage in rat sperm cells in vivo and in vitro. Free Radic. Res. 32: 75-83. 